\title{
Hydrodynamic transmission operating with two-phase flow
}

\author{
M. Bărglăzan, C. Velescu, T. Miloş, A. Manea, E. Dobândă \\ \& C. Stroiță \\ "Politehnica" University of Timişoara, Romania
}

\begin{abstract}
Heavy automotive vehicles and automobiles are, almost exclusively, equipped with automatic hydrodynamic transmissions. This article is devoted to one of the possibilities to control the operation of hydrodynamic transmissions through partially filling the torque converter with liquid. The investigation was centred on torque converters with two-phase flows, namely oil-air. There are proposed theoretical, numerical models and an experimental facility, testing rig, was erected.

The obtained results are in the hydrodynamic field (velocities and pressures) in the torus and the characteristic curves of the two-phase flow hydrodynamic transmission.

Keywords: hydrodynamic transmission, torque converter, two-phase flow, numerical models, experimental facility, characteristic curves.
\end{abstract}

\section{Introduction}

Torque converters are now commonly used in a wide variety of applications requiring smooth torque transmission, most notably in automobiles. They usually consist of an input shaft that drives a pump impeller and one or more added set stator vanes, and between them the turbines stage runners that transmit the torque to an output shaft coaxial with the input shaft.

All this, inside the hydrodynamic circuit, forms a torus filled with fluid, which is usually hydraulic oil. The device is normally equipped with a cooling system to dissipate the generated heat. 
In the present paper we present a Lysholm-Smith type torque converter and we investigated, both theoretically and with experiments, its behaviour with partial filling of the torus, so we have a two-phase flow oil-air in the hydraulic transmission.

\section{Numerical simulation of the flow in the $\mathrm{CHC}-350$ torque converter}

The torque converter $\mathrm{CHC}-350$ has the shape and size of the hydraulic circuit (torus) given in figure 1.

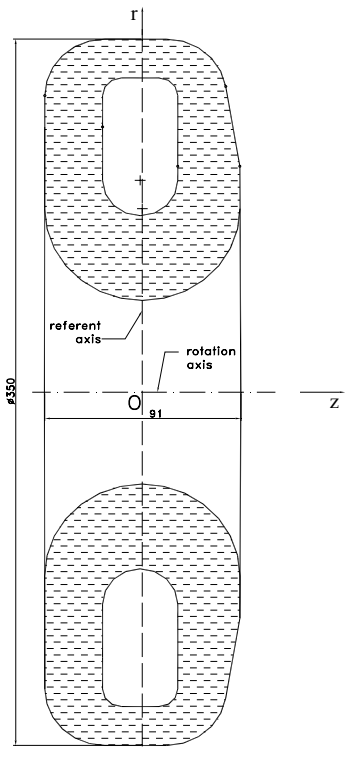

(a)

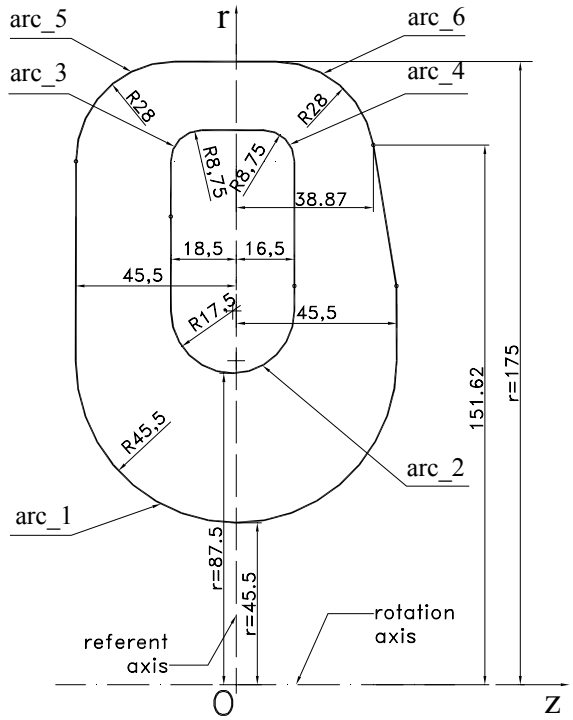

(b)

Figure 1: $\quad$ Shape and size of the hydraulic circuit of the torque converter: (a) complete section, (b) superior half section versus rotating axis.

The flow in the meridian plane was simulated trough the FEM. It was considered the axial-symmetry and half of the circuit is presented in figure 1 (b). The modality to solve the problem of the hydrodynamic closed circuit proposed two serial domains of flow connected with reciprocal influence between them.

The partial derivate equation of the flow function $\psi$ is a Helmholtz equation of an elliptical type in cylindrical coordinates:

$$
\frac{\partial^{2} \psi}{\partial z^{2}}+\frac{\partial^{2} \psi}{\partial r^{2}}-\frac{1}{r} \frac{\partial \psi}{\partial r}=0
$$

The meridian speed modulo is calculated for every element with the relation:

$$
v_{m}^{e}=\sqrt{\left(v_{z}^{e}\right)^{2}+\left(v_{r}^{e}\right)^{2}}
$$


The pressure coefficient $\mathrm{C}_{\mathrm{p}}$ is given by:

$$
\bar{p}=C_{p}=\frac{p-p_{0}}{\rho \frac{v_{0}^{2}}{2}}=1-\left(\overline{v_{m}}\right)^{2}
$$

where $\overline{v_{m}}=v_{m} / v_{0 . .}$ The flow and equipotential lines are given in figure 2.

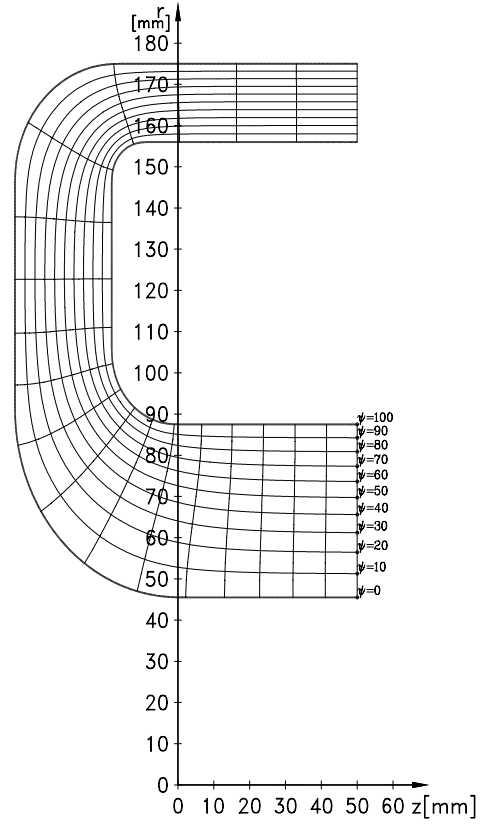

(a)

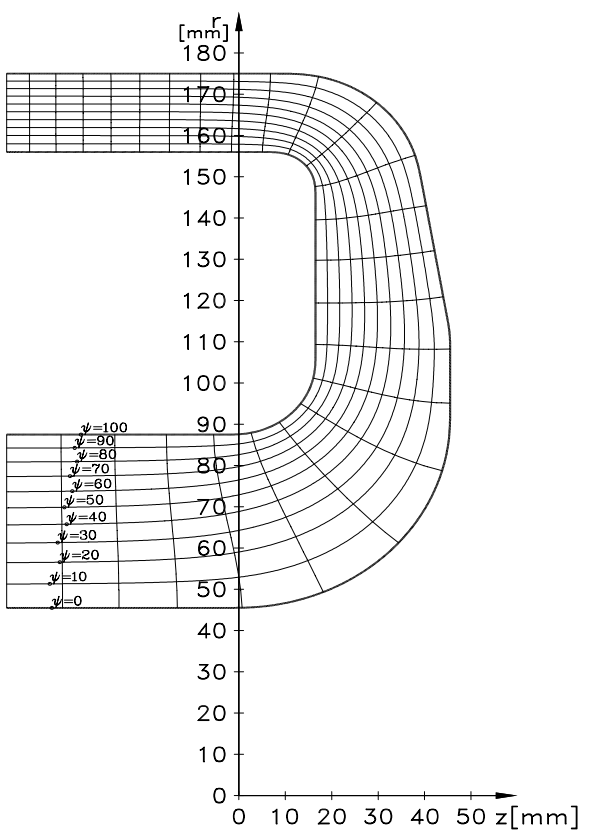

(b)

Figure 2: Flow and equipotential lines of the hydrodynamic spectrum: (a) left-side extended domain, (b) right-side extended domain.

Solving this problem, here, was obtained the flow-map presented in figures 3 and 4.

Figures 3 and 4 shows the velocities and pressures occurring inside the torus during the rated operation of the torque converter.

\section{Experimental investigations}

The testing facility of hydraulic transmissions is located in the Laboratory of Hydraulic Machinery from "Politehnica" University of Timişoara (LMHT). The facility is presented in figure 5 . 


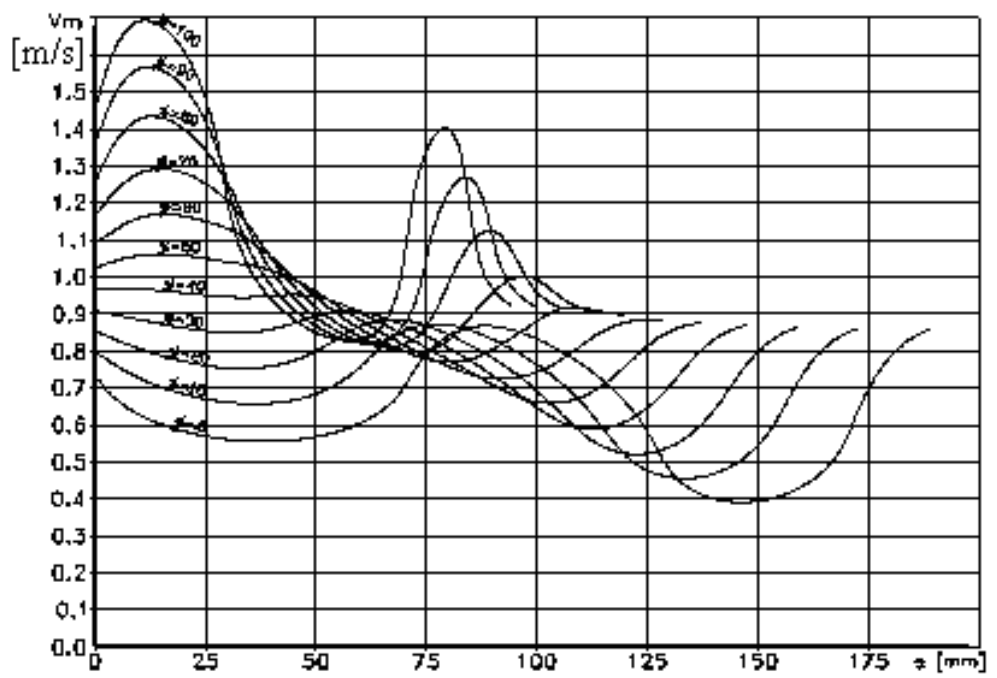

(a)

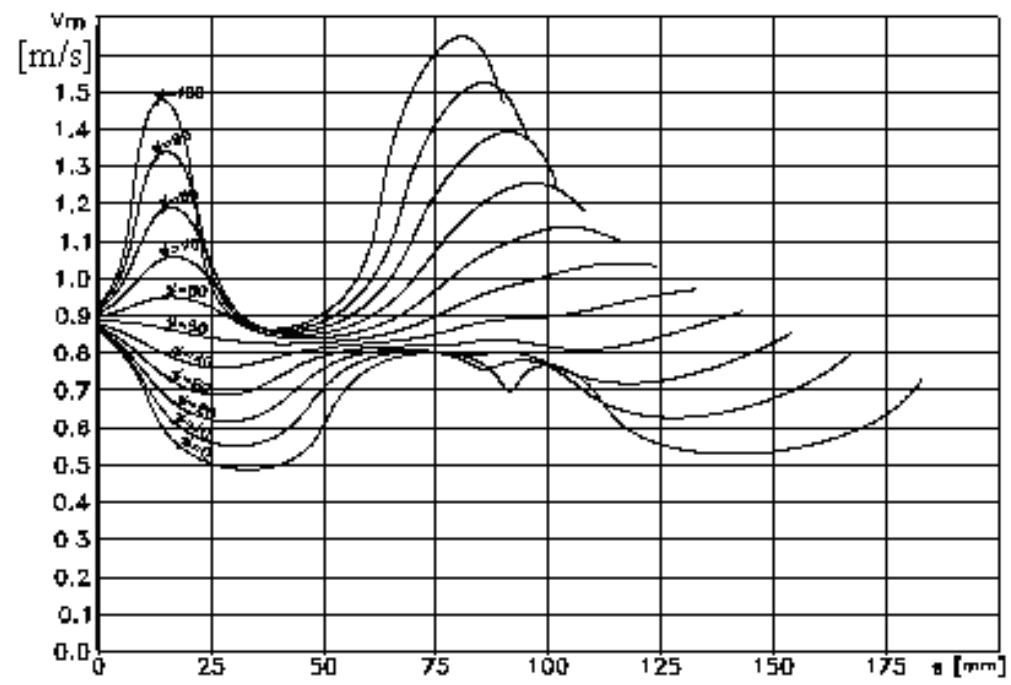

(b)

Figure 3: Variation of the speeds along flow lines: (a) left domain, (b) right domain.

The facility consists from o testing rig with the following components:

- $\quad \mathrm{OG}$ - oil group

$$
\begin{aligned}
& >\mathrm{P}-\text { pump } \\
& >\quad \mathrm{OR}-\text { oil reservoir } \\
& >\quad \mathrm{CR}-\text { cooler radiator }
\end{aligned}
$$


- $\quad$ EM 1, 2, 3 - electrical motors

- $\mathrm{TC}$ - torque converter

- $\mathrm{T}_{-} \mathrm{t}$ - torque transducer

$>\mathrm{TB}$ - tensometric bridge

- $\quad$ EG 1, 2, 3 - electrical generators

- $\quad \mathrm{ERG}$ - electrical regenerative group

$>$ RE - variable resistor

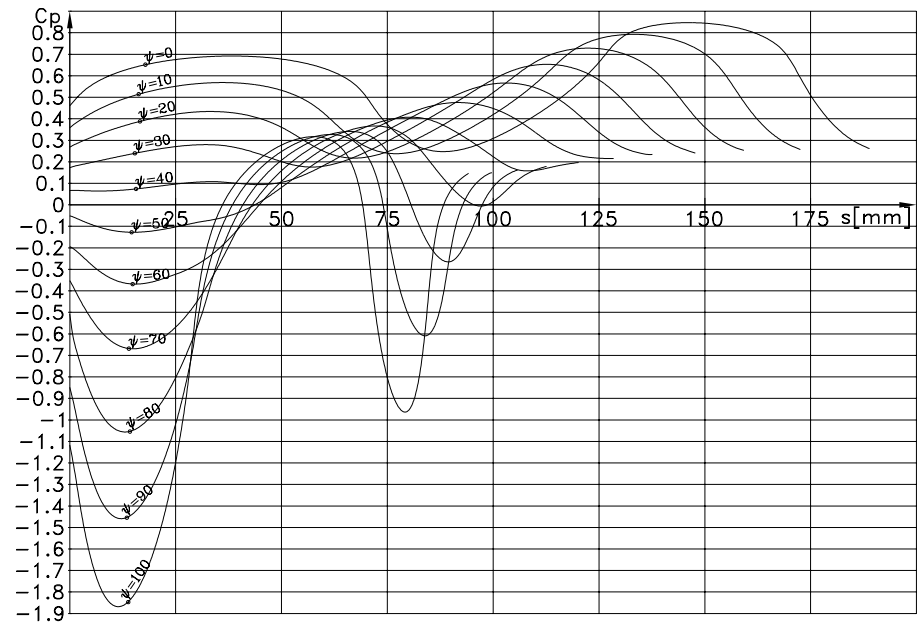

(a)

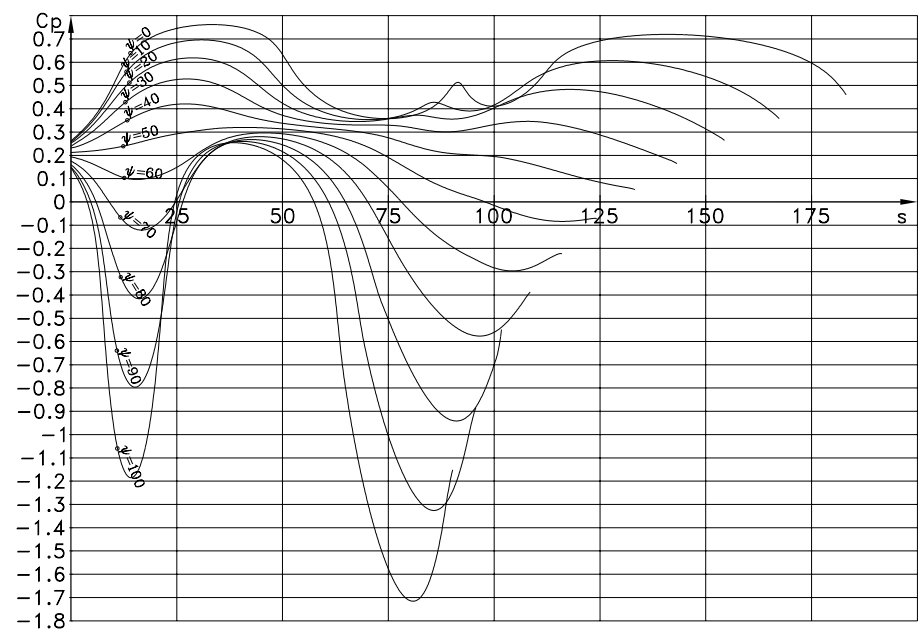

(b)

Figure 4: Variation of the pressure coefficient $\mathrm{Cp}$ along flow lines: (a) left domain, (b) right domain. 


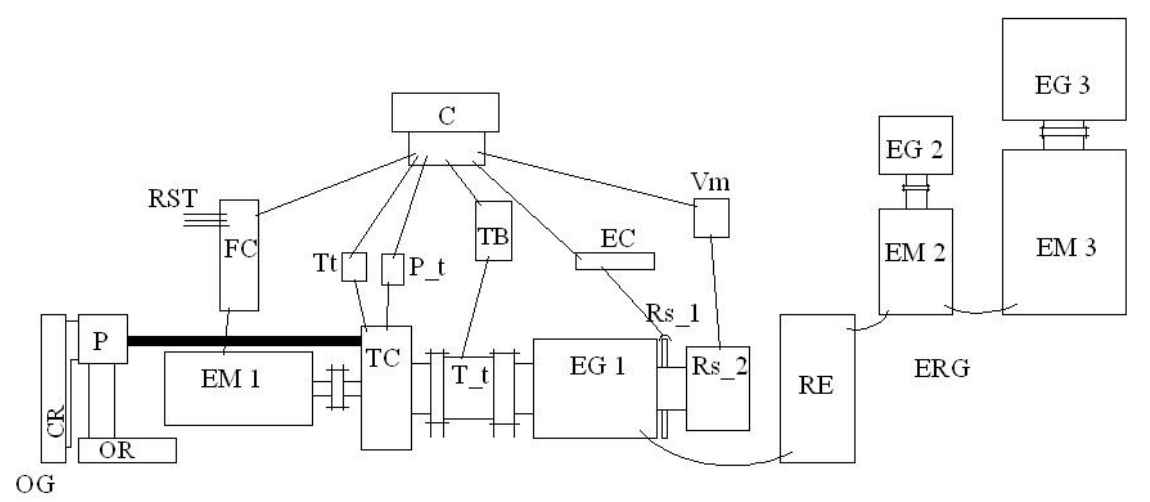

Figure 5: $\quad$ The $\mathrm{CHC}-350$ torque converter testing rig.

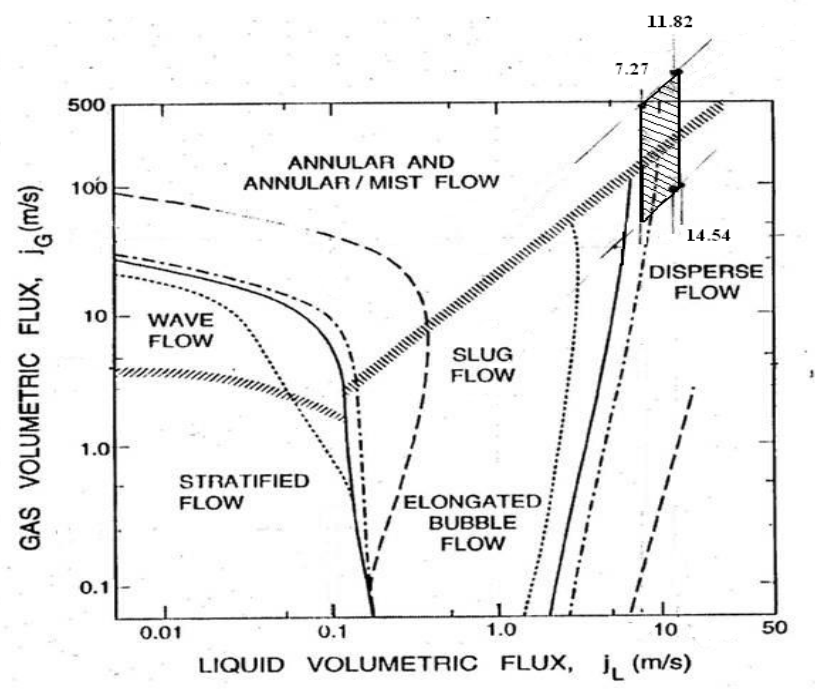

Figure 6: $\quad$ Two-phase flow-map after [2].

- $\quad \mathrm{FC}-$ frequency converter

- Rs_1, Rs_2-rotational speed transducers

$>\overline{\mathrm{E}} \mathrm{C}-$ electronic counter

$>\mathrm{Vm}$ - voltmeter

- $\mathrm{Tt}$ - temperature transducer

- $\quad \mathrm{P} \_\mathrm{t}-$ pressure transducer

- $\mathrm{C}$ - computer

Knowing the speed of rotation range investigated between 600 and 1200 rev/min- and the filling degree - between $100 \%$ and $70 \%$ oil - it was possible to establish the flow regime of the gas/liquid mixture. Introducing the 
approximately calculated parameters from the above given data, quantitative results could be introduced in the two-phase flow map given in [2]. The marked zone (domain) in figure 5 was obtained. The first hand conclusion is that in quite all regimes of flow inside the torque converter's torus it develops a homogeneous disperse flow.

To study the influence of heat developed during the torque converter operation the cooling hydraulic circuit was closed. The temperature rise trough the torque converter operation in different regimes of filling degree and braking capacity was strictly monitored and one of the obtained set of curves is given in figure 7 .

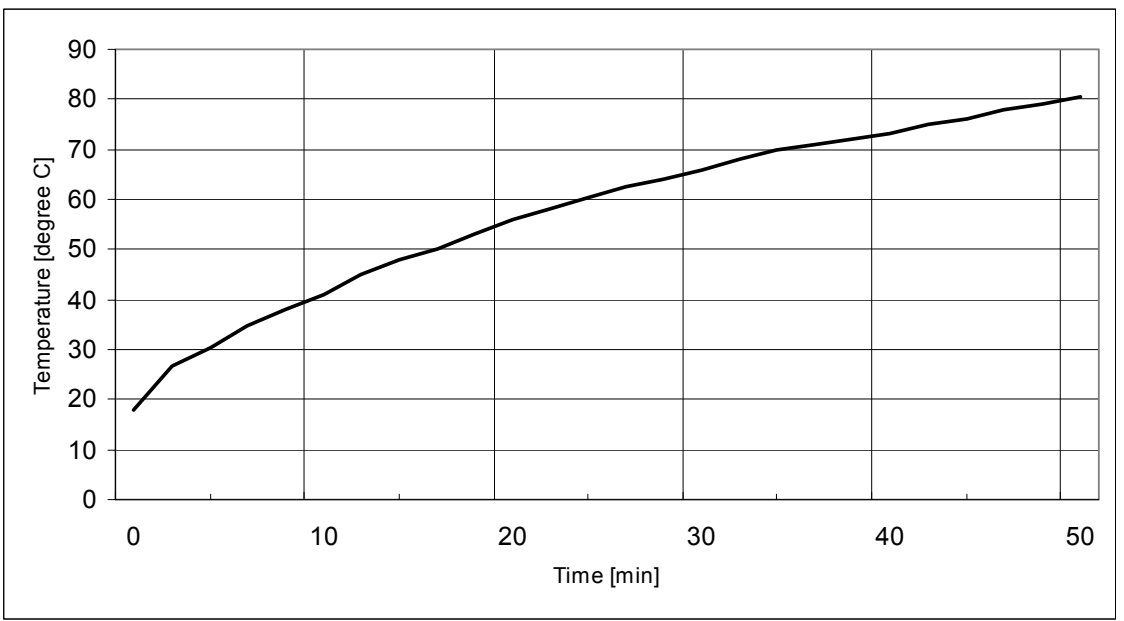

Figure 7: Oil temperature versus time inside the CHC-350 torque converter.

The partial conclusion is that it is advisable to measure the mean parameters of the torque converter somewhere between 33 and 50 minutes from the start corresponding to a temperature range of 70-90 degrees Celsius. Testing the CHC-350 torque converter the experiment results were obtained in the shape of plotted primary characteristics, such as figure 8 and the comprehensive universal characteristics sets of curves in figures 9 and 10 .

The used formulas are:

$$
\mathrm{i}=\mathrm{n}_{2} / \mathrm{n}_{1}
$$

for the ratio of turbine to pump speed and

$$
\eta=\frac{P_{2}}{P_{1}}=\frac{n_{2} \cdot M_{2}}{n_{1} \cdot M_{1}}
$$

the torque converter efficiency (eta) as a function of speeds $n 1$ and $n_{2}$ and the turbine, $\mathrm{M}_{2}$, and pump, $\mathrm{M}_{1}$, torques. All the measurements were made for different volumetric degrees of filling $\mathrm{X}_{\mathrm{u}}$ (chiu). 


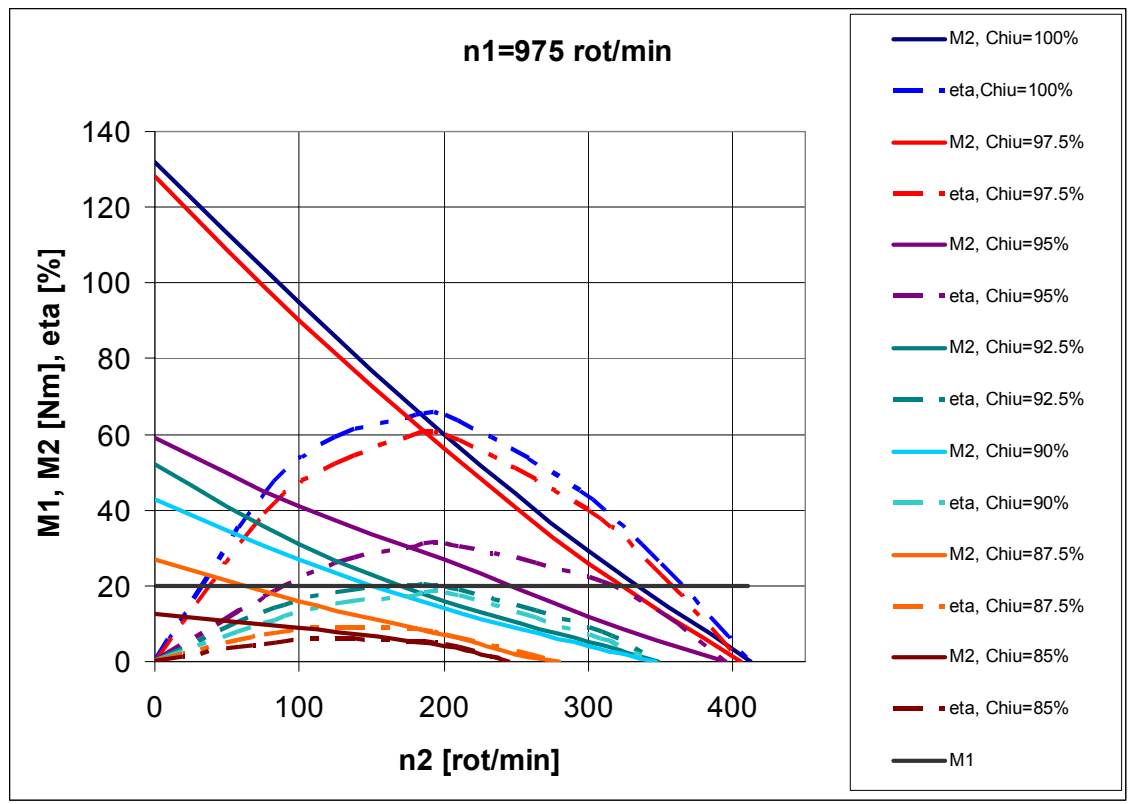

Figure 8: Primary characteristics of the CHC-350 torque converter with constant filling degree.

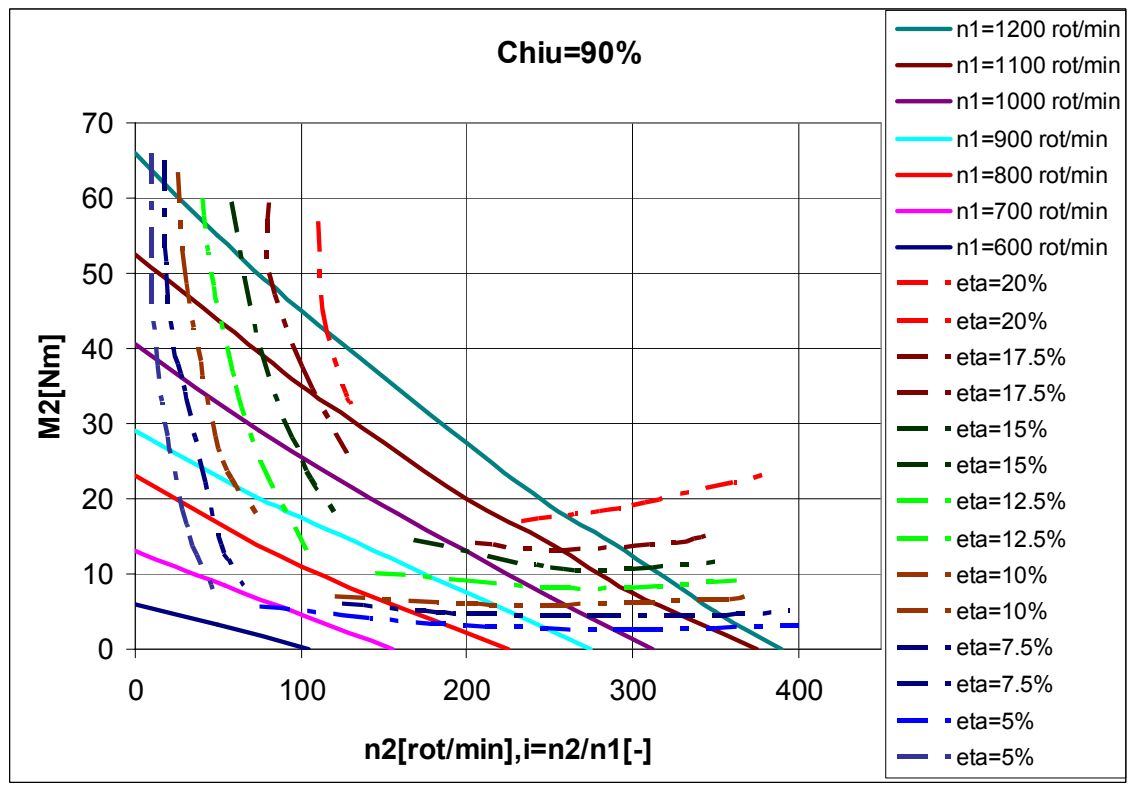

Figure 9: The universal characteristics of the CHC-350 torque converter with constant filling degree. 


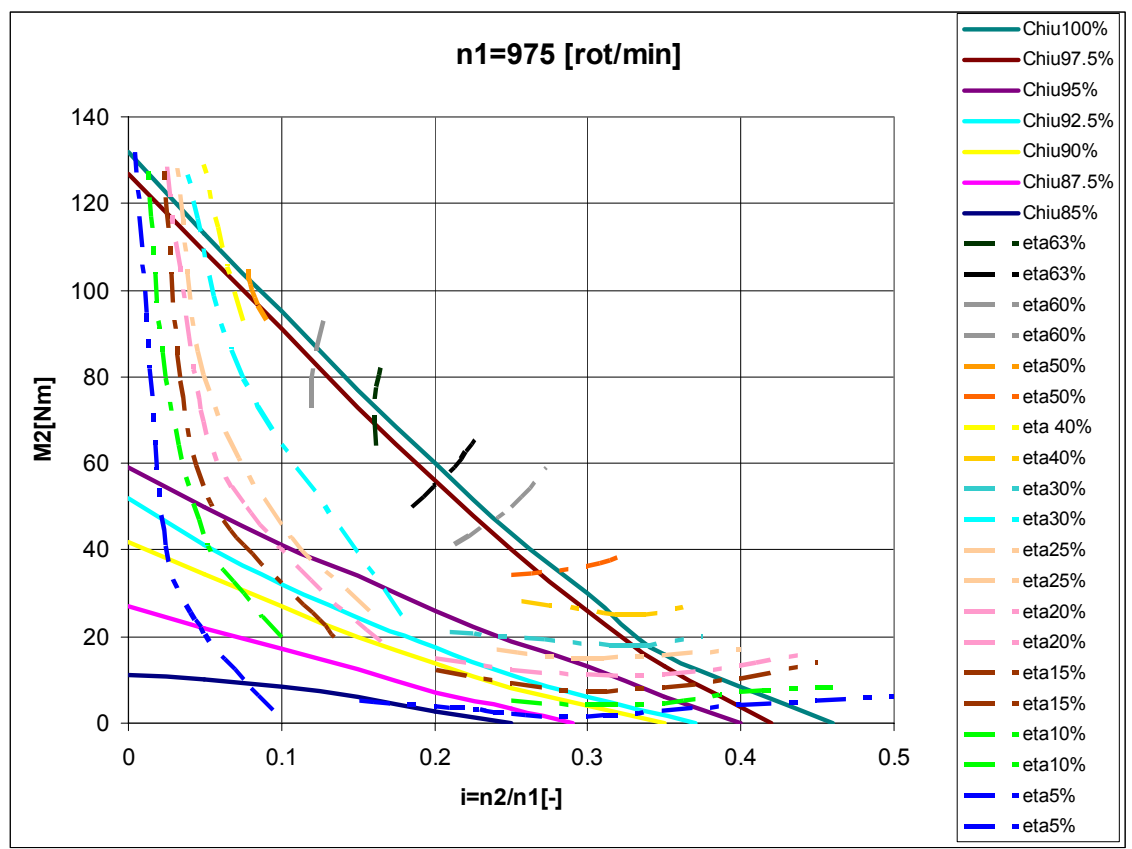

Figure 10: Universal characteristics of the $\mathrm{CHC}-350$ torque converter with variable filling degree.

\section{Conclusions}

The torque converter type CHC-350 operating with two-phase flow, namely oil-air showed the following features:

- A quite linear influence on the performance of the torque converter with different degrees of filling in the range of $80 \%$ to $100 \%$ oil in the transmission's torus.

- Rated parameter decreasing of the hydraulic transmission with the reducing of filling degree (chiu).

- The utilizable degree of filling is between $100 \%$ and $70 \%$ oil

- The primary characteristic curves, figure 8 , give the possibility to estimate the torque, speed and efficiency of the transmission.

- The universal characteristic set of curves, figure 9 and figure 10, shows the optimum parameters of the torque converter.

- The possibility to control the torque converter's performances through the variable degree of filling.

- The two-phase flow structure inside the torque converter torus is very various depending on the torus geometry, rotational speed, degree of filling and fluid pressure. 


\section{References}

[1] M. Bărglăzan, C. Velescu, Cuplaje, transformatoare şi frâne hidrodinamice, ed. Politehnica: Timişoara, pp. 68-72, 2006.

[2] C. Brennen, Fundamentals of Multiphase Flow, Cambridge University Press: Cambridge, pp. 165-181, 2005.

[3] T. Miloş, Computer Aided Design Optimization of the Centrifugal Pump Runner, Proc. of the Workshop on Numerical Simulation of Fluid Mechanics, ed. Orizonturi Universitare: Timişoara, pp. 69-78, 2001.

[4] E, Dobândă, The Dynamic Behaviour of Torque Converters, $X I^{\text {th }}$ International Conference "Man in knowledge based organization": Sibiu, pp. 126-132, 2006.

[5] R. R. By, B. Lakshminarayana, Measurement and Analysis of Static Pressure Field in a Torque Converter Pump, ASME Journal of Fluids Engineering, no. 1, pp.109-115, 1995.

[6] B. A. Gavrilenco, V. A. Minin, Ghidrodinamiceschie mufti, Oboronghiz: Moscva, pp. 116-171, 1959.

[7] N. Peligrad, Cuplaje hidraulice şi convertizoare hidraulice de cuplu, ed. Tehnică: Bucureşti, pp. 246-250, 1985.

[8] A. Bărglăzan, V. Dobândă, Turbotransmisiile hidraulice, ed. Tehnică: Bucureşti, pp. 267-283, 1957.

[9] Iu. F. Ponomarenco, Ispîtanie ghidroperedaci, Izdat. Maşinostroenie: Moscva, pp. 97-116, 1969. 